\title{
COMPARISON OF CHEWING ABILITY, ORAL HEALTH RELATED QUALITY OF LIFE AND NUTRITIONAL STATUS BEFORE AND AFTER INSERTION OF COMPLETE DENTURE AMONGST EDENTULOUS PATIENTS IN A DENTAL COLLEGE OF PUNE
}

\author{
Sonawane Madhuri ${ }^{1}$, Shetiya Sahana Hegde ${ }^{1}$, Shirahatti Ravi², Agarwal \\ Deepti $^{1}$, Mahuli Simpy ${ }^{1}$
}

\section{ABSTRACT}

BACKGROUND: The relationship between tooth loss and nutritional intake is important. As people age, their diminished physical capacity and decreased income adversely affect their ability to maintain their teeth. The aim of the study was to assess and compare the chewing ability, oral health related quality of life and nutritional status before and after fabrication and insertion of complete denture amongst edentulous participants in a dental college.

MATERIAL AND METHODS: Non Randomized Intervention study. The study population consisted of 42 participants (16 females and 26 males), aged 50 years and above. Prior to commencement of the study, informed consent was obtained and validation and reliability test of the questionnaire were done. The data for chewing ability, GOHAI and nutritional status assessment was recorded at baseline, $3^{\text {rd }}, 6^{\text {th }}$ and $12^{\text {th }}$ month after denture fabrication and insertion. The statistical comparisons were performed by repeated measure ANOVA and Chi-square test. P value $<0.05$ was considered as statistically significant.

RESULTS: Chewing ability, GOHAI, BMI (Body Mass Index) and data from Food-intake questionnaire showed statistically significant improvement from baseline to $6^{\text {th }}$ month but no statistically significant improvement was observed from $6^{\text {th }}$ month to $12^{\text {th }}$ month. Nutritive value of food (protein, energy and fat) showed no significant difference over a period of 12 months $(p<0.05)$.

Conclusion: Thus, it was concluded that the intervention (denture insertion) was effective in increasing the chewing ability, body weight, food-intake, and oral health related quality of life.

KEYWORDS: nutrition, edentulousness, OHQoL, GOHAI, chewing ability

DOI: http://dx.doi.org/10.4314/ejhs.v24i3.9

\section{INTRODUCTION}

Tooth loss is an age related problem. As the age advances, people's ability to maintain their teeth is affected due to their reduced physical capacity and income (1). Relationship between masticatory function and impaired food intake for fully edentulous patients has been described in literature (2).
Masticatory ability and food selection are majorly affected by loss of teeth forcing elderly edentulous people to choose soft and easy to chew foodstuff when compared with dentate individuals $(3,4,5)$. Edentulous individuals frequently report more chewing difficulties than dentate people, and they therefore constitute the group most likely to change their diet (6).

\footnotetext{
${ }^{1}$ Dept of Public Health Dentistry, Dr. D.Y Patil Dental College \& Hospital, Dr.D Y Patil, Vidyapeeth Pune, Maharashtra, India

${ }^{2}$ Dept of Public Health Dentistry, ABSM Institute of Dental Science, Karnataka, India

Corresponding Author: Shetiya Sahana Hegde, Email: hegdesahana@hotmail.com
} 
Loss of teeth can substantially affect oral and general health, enjoyment with food and overall nutrition thereby affecting the quality of life (7). Oral health-related quality of life (OHRQoL) is a subset of health-related quality of life (HRQoL). The GOHAI (General Oral Health Assessment Index) is a 12-items self-reported index used to assess three dimensions: physical functions, psychosocial functions and pain or discomfort $(6,8)$. The GOHAI has been recommended for use as an outcome measure in the evaluation of dental treatment (9). There is no gold standard for determining nutritional status and no universally accepted criteria to define malnutrition (10). As foods differ in their nutrient content, it is necessary to know about essential nutrients, their food sources and their needs. The booklet of nutritive values of some Indian food preparations provides information of energy, protein and fat values of food preparations as consumed in the communities of middle and lower middle socioeconomic status groups $(11,12)$. Hence, in the present study, the nutritive value assessment was done by calculating the energy, fat and protein values for some Indian food preparations.

India has a large geriatric population of 77 million, comprising $7.7 \%$ of its total population. One of the major handicaps among the elderly is loss of teeth, affecting their mastication, dietary intake and nutritional status (13). According to the national oral health survey of 2002-2003, about $29 \%$ of the population in the age group of 65 to 74 years requires complete dentures in Maharastra State, while only $3.1 \%$ are using it (14). Very few studies have been conducted in India to see the effect of complete dentures on chewing ability, oral health related quality of life and nutritional status' i.e. there is need of adequate data in this regard. Therefore, this study was conducted to compare the chewing ability, oral health related quality of life and nutritional status before and after insertion of complete denture among edentulous patients visiting a dental college in Pune.

\section{MATERIAL AND METHODS}

A non-randomized Intervention study was conducted from Jan 2012-Feb 2013. Before the commencement of the study, approval from the ethical committee of Dr D.Y. Patil Dental College and Hospital, Dr. D.Y. Patil Vidyapeeth, Pune, and written informed consent was obtained.

A convenience sampling of 42 individuals (16 females and 26 males), aged 50 years and above, visiting a dental college for complete dentures were recruited for the study. All the subjects aged 50 years and above, reporting to the Out Patients Department of the Department of Prosthodontics with the chief complaint of complete edentulousness were recruited for the study till the desired sample size was obtained. Sample size was calculated based on mean and standard deviation of a previous study (4) in which nutrition status was assessed by calculating dietary parameter i.e. fat, among first and second time denture wearers. Sample size was calculated using this information in nMaster1.0 (Biostatistics Resource and Training Centre, Christian Medical College, Vellore, India) with power of $80 \%$ and alpha error of 5\% (2 sided). Before insertion of denture, i.e. pretest mean and standard deviation for fat was $34.85 \pm 8.94$, after 6 months i.e. Posttest mean and standard deviation was $41.63 \pm 20.12$ for fat. The minimum sample size was calculated to be 38. The sample size was increased by approximately $25 \%$ to account for loss to follow up. Forty eight patients were included in the study. Six patients did not respond at the follow up visits; hence; they were excluded and the remaining 42 patients were finally assessed.

Nine experts were consulted to test the face and content validities of the questionnaire for chewing ability, GOHAI and nutritional status, and wherever necessary, changes were made in the questionnaire. Questions having content validity ratio (CVR) of 0.7 were included in the final questionnaire. After validation, the questionnaire was translated into Marathi, the local language, for the convenience of participants. The Marathi version was translated back into English by an English translator who had not seen the original version. The equivalence between the original questionnaire and the back translated version was supported by an expert committee consisting of two experts in both English and Marathi languages. A pilot study on ten patients following the inclusion and exclusion criteria was conducted. For Test-retest reliability purpose, the patients were given the questionnaire at two different occasions to check the reproducibility of the questionnaire. Internal consistency 
(Cronbach's alpha) for questionnaire was excellent (1.0). A single examiner underwent training and calibration procedure after validation of the questionnaire. The examiner was calibrated for recording height and weight of the study population which showed $80 \%$ agreement.

The study tools used were: 1) chewing ability questionnaire, 2) GOHAI questionnaire, 3) nutritional assessment questionnaire (Eight questions and 24 hour diet chart) and 4) Height and weight measurement for calculation of Body Mass Index $\left(\mathrm{BMI}=\mathrm{kg} / \mathrm{m}^{2}\right)$.

Data collection was carried out in two phases. Phase one included collection of data before insertion (baseline) of complete denture (January March 2012) followed by insertion of complete denture, and phase two included collection of data after insertion and use of complete denture at $3^{\text {rd }}$, $6^{\text {th }}$ and $12^{\text {th }}$ months. The chewing ability questionnaire had 16 food items(Rice, Paratha, Chapatti/Pulka, Biscuits, fruits and vegetables, Bhakri (jowar, bajra), Meat/soya bean,) which patients had to rate as not able to chew or able to chew. A summative score of 0 to 16 was calculated for each patient. The 11 items of GOHAI was administered using a 6-point scale (never $=0$, Seldom $=1$, Sometime $=2$, Often $=3$, Very-often $=4$, Always $=5$ ). GOHAI scale scores at baseline, $3^{\text {rd }}, 6^{\text {th }}$ and $12^{\text {th }}$ months were calculated as a simple summation of the 11 item after reversing the response set three items (item 2: able to swallow comfortably; item 4: eat anything without feeling discomfort; item 6: happy with looks). Reversing for the questions no
2,4 , and 6 indicated the higher the score the better oral health. A simple summative score ranging from 0 to 55 was calculated for each patient, with a higher score indicating better Quality of life. Nutritional status assessment consisted of food intake questionnaire (eight questions) and one day diet chart which was recorded at baseline and at the end of $3^{\text {rd }}, 6^{\text {th }}$ and $12^{\text {th }}$ months along with Body Mass Index.

Data was analyzed using Statistical Package for Social Sciences (SPSS) for windows version 16.0. Changes in chewing ability, Oral Health Related Quality of Life and nutritional status before and after insertion of complete denture were analyzed using repeated measure analysis of variance (ANOVA) followed by Post hoc test. Change in food intake over a period of 12 months was assessed using Mc Nemars test. Statistical significance was set at the level $P<0.05$.

\section{RESULTS}

The demographic characteristics of 42 patients are as follows. There were 21 patients in $50-60$ years age group, 14 in 61-70 years age group, 5 in 71-80 years and 2 in 81 and above years of age. The data showed that the majority of the participants were from the age group of 50-60 years. Mean age was 62 years. Twenty-six males and 16 females were included in this study. The Kuppuswamy's socioeconomic status (15) scale was modified for June 2011, out of which $4 \%$ were from lower middle class, $69 \%$ participants were from upper lower class and $26 \%$ were from lower class.

Table 1: Comparison of change in chewing ability among participants at baseline, (before insertion and fabrication of complete denture) $3^{\text {rd }}$, 6th and $12^{\text {th }}$ months post insertion.

\begin{tabular}{|c|c|c|c|c|c|c|c|c|c|c|c|}
\hline \multirow[t]{2}{*}{ Chewing ability } & & \multirow{2}{*}{\multicolumn{2}{|c|}{ Mean }} & \multirow[t]{2}{*}{$\mathrm{SD}$} & \multicolumn{4}{|c|}{$95 \%$ confidence Interval } & \multirow[t]{2}{*}{$\mathrm{N}$} & \multirow[t]{2}{*}{$\mathrm{F}$} & \multirow[t]{2}{*}{$\mathrm{P}$ value $^{\mathrm{a}}$} \\
\hline & & & & & \multicolumn{2}{|l|}{ lower } & \multicolumn{2}{|l|}{ Upper } & & & \\
\hline \multirow[t]{4}{*}{ Able to chew } & Baseline & \multicolumn{2}{|l|}{2.71} & 1.33 & \multicolumn{2}{|l|}{2.30} & \multicolumn{2}{|l|}{3.12} & \multirow{4}{*}{42} & \multirow{4}{*}{376.4} & \multirow{4}{*}{0.00} \\
\hline & $3^{\text {rd }}$ month & \multicolumn{2}{|l|}{11.14} & 2.29 & \multicolumn{2}{|l|}{10.42} & \multicolumn{2}{|l|}{11.85} & & & \\
\hline & $6^{\text {th }}$ month & \multicolumn{2}{|l|}{11.54} & 2.13 & \multicolumn{2}{|l|}{10.88} & \multicolumn{2}{|l|}{12.21} & & & \\
\hline & $12^{\text {th }}$ month & 11.54 & & 2.13 & \multicolumn{2}{|l|}{10.88} & \multicolumn{2}{|l|}{12.21} & & & \\
\hline \multicolumn{12}{|c|}{ Post-Hoc $^{b}$} \\
\hline \multicolumn{12}{|c|}{ Able to chew } \\
\hline \multicolumn{3}{|l|}{ Baseline } & \multicolumn{5}{|c|}{$3^{\text {rd }}$ month } & \multicolumn{4}{|c|}{$6^{\text {th }}$ month } \\
\hline $3^{\text {rd }}$ month & $6^{\text {th }}$ month & $12^{\text {th }}$ month & Baseline & \multicolumn{2}{|c|}{$6^{\text {th }}$ month } & $12^{\text {th }}$ & onth & \multicolumn{2}{|c|}{ Baseline } & $3^{\text {rd }}$ month & $12^{\text {th }}$ month \\
\hline 0.00 & 0.00 & 0.00 & 0.00 & 1. & & 1.00 & & 0.01 & & 1.00 & \\
\hline
\end{tabular}

a: Repeated measure ANOVA used for intra-group comparison at different time intervals

b: Post-hoc testing of ANOVA: Bonferroni, $P$ value significant at $5 \%$ level of significance $(\mathrm{p}<0.05)$ 
Table 1 shows the within-group comparison of chewing ability scores of patients at baseline, $3^{\text {rd }}$, $6^{\text {th }}$ and $12^{\text {th }}$ month. There was a highly statistically significant increase in chewing ability among patients from baseline to 12 months $(\mathrm{p}=0.00)$. However, from the $3^{\text {rd }}$ month to the $12^{\text {th }}$ month statistical significance was not seen.

Table 2 shows the within-group comparison of GOHAI scores in patients at baseline, $3^{\text {rd }}, 6^{\text {th }}$ and $12^{\text {th }}$ months. Intensity of GOHAI scores showed a highly statistically significant increase in patients wearing complete denture from baseline to 12 months, but no statistically significant difference was seen from $3^{\text {rd }}$ month to $12^{\text {th }}$ month. On the other hand Table 3 shows before and after comparison of food intake amongst patients at baseline and 12 months which was found to be statistically significant.

Table 2: Comparison of change in GOHAI among participants between the baseline, $3^{\text {rd }}$, 6th and $12^{\text {th }}$ months after insertion of complete denture

\begin{tabular}{|c|c|c|c|c|c|c|c|c|}
\hline \multirow[t]{2}{*}{ GOHAI } & \multirow[t]{2}{*}{ Mean } & \multirow[t]{2}{*}{ SD } & \multicolumn{3}{|c|}{$95 \%$ confidence Interval } & \multirow[t]{2}{*}{$\mathrm{N}$} & \multirow[t]{2}{*}{$\mathrm{F}$} & \multirow[t]{2}{*}{$\mathrm{P}_{\text {value }}{ }^{\mathrm{a}}$} \\
\hline & & & \multicolumn{3}{|c|}{\begin{tabular}{|l|l|} 
Lower & Upper \\
\end{tabular}} & & & \\
\hline Baseline & 21.11 & 4.47 & 19.72 & 22.51 & & \multirow{4}{*}{42} & \multirow{4}{*}{592.0} & \multirow{4}{*}{0.00} \\
\hline $3^{\text {rd }}$ month & 39.26 & 2.20 & 38.57 & \multicolumn{2}{|l|}{39.95} & & & \\
\hline $6^{\text {th }}$ month & 40.04 & 1.16 & 39.68 & \multicolumn{2}{|l|}{40.41} & & & \\
\hline $12^{\text {th }}$ month & 40.19 & 1.15 & 39.83 & 40.55 & & & & \\
\hline \multicolumn{9}{|c|}{ Post-Hoc ${ }^{b}$} \\
\hline \multicolumn{3}{|c|}{ Baseline } & \multicolumn{3}{|c|}{$3^{\text {rd }}$ month } & \multicolumn{3}{|c|}{$6^{\text {th }}$ month } \\
\hline $3^{\text {rd }}$ month & $6^{\text {th }}$ month & $\begin{array}{l}12^{\text {th }} \\
\text { month }\end{array}$ & Baseline & $6^{\text {th }}$ month & $\begin{array}{l}12^{\text {th }} \\
\text { month }\end{array}$ & Baseline & $3^{\text {rd }}$ month & $\begin{array}{l}12^{\text {th }} \\
\text { month }\end{array}$ \\
\hline 0.00 & 0.00 & 0.00 & \begin{tabular}{|l|}
0.00 \\
\end{tabular} & 0.35 & 0.23 & 0.00 & 0.35 & 1.00 \\
\hline
\end{tabular}

a: Repeated measure ANOVA used for intra-group comparison at different time intervals

$\mathrm{b}$ : Post-hoc testing of ANOVA: Bonferroni

$P$ value significant at $5 \%$ level of significance $(p<0.05)$

Table 3: Percentage distribution of change in food intake among participants from baseline to $12^{\text {th }}$ months after insertion of complete denture

\begin{tabular}{|l|l|l|l|}
\hline \multicolumn{1}{|c|}{ Questions } & $\begin{array}{l}\text { Baseline } \\
\text { pre-insertion } \\
\mathrm{N}(\%)\end{array}$ & $\begin{array}{l}12^{\text {th }} \text { month } \\
\text { post-insertion } \\
(\%)\end{array}$ & P value \\
\hline Current appetite.(Good) & $4141(97 \%)$ & $4242(100 \%)$ & $\mathbf{0 . 0 0}_{*}$ \\
\hline Food intake Less than usual.(Yes) & $36(85 \%)$ & $9(21 \%)$ & $\mathbf{0 . 0 0}^{*}$ \\
\hline $\begin{array}{l}\text { Mouth or swallowing problem that makes it } \\
\text { hard to eat.(Yes) }\end{array}$ & $41(97 \%)$ & $9(21 \%)$ & $\mathbf{0 . 0 0}^{*}$ \\
\hline Skip meal(Yes) & $37(88 \%)$ & $34(80 \%)$ & $\mathbf{0 . 5 0}$ \\
\hline Allergies or intolerance to food.(Yes) & $7(16 \%)$ & $4(9 \%)$ & $\mathbf{0 . 5 0}^{*}$ \\
\hline Change in kind of food due to illness.(Yes) & $37(88 \%)$ & $13(30 \%)$ & $\mathbf{0 . 0 1}^{*}$ \\
\hline Consumption of protein & $36(85 \%)$ & $42(100 \%)$ & $\mathbf{0 . 0 3}^{*}$ \\
\hline Consumption of Fruits and vegetables. (Yes). & $20(47 \%)$ & $29(69 \%)$ & $\mathbf{0 . 0 1}^{*}$ \\
\hline
\end{tabular}

*Statistically significant difference by McNemar

Table 4 shows the within-group comparison of nutritive value of food preparations for the patients at the baseline, $3^{\text {rd }}, 6^{\text {th }}$ and $12^{\text {th }}$ months, which was not statistically significant over time for energy and fat, whereas, protein showed slightly significant difference from baseline to 12 months respectively. However, post hoc test for protein does not reveal significant difference.

Figure 1 shows the within-group comparison of BMI scores of patients wearing denture increasing from baseline to $3^{\text {rd }}$ and $6^{\text {th }}$ month respectively. 
Table 4: Comparison of change in nutritive (energy, protein, fat) value of food preparations among participants at baseline, (before insertion) $3^{\text {rd }}, 6^{\text {th }}$ and $12^{\text {th }}$ months (after insertion of complete denture).

\begin{tabular}{|c|c|c|c|c|c|c|c|c|c|}
\hline \multirow{2}{*}{\multicolumn{3}{|c|}{ Nutrition }} & \multirow[t]{2}{*}{ Mean } & \multirow[t]{2}{*}{ SD } & \multicolumn{2}{|c|}{$95 \%$ confidence Interval } & \multirow[t]{2}{*}{$\mathrm{F}$} & \multirow[t]{2}{*}{$\mathrm{N}$} & \multirow[t]{2}{*}{$\mathrm{P}$ value $^{\mathrm{a}}$} \\
\hline & & & & & lower & \multirow{2}{*}{ upper } & & & \\
\hline \multirow[t]{4}{*}{ Energy } & \multicolumn{2}{|l|}{ Baseline } & 1075.0 & 259.09 & 994.2 & & \multirow{4}{*}{2.16} & \multirow{4}{*}{42} & \multirow{4}{*}{0.12} \\
\hline & \multirow{2}{*}{\multicolumn{2}{|c|}{$\begin{array}{l}3^{\text {rd }} \text { month } \\
6^{\text {th }} \text { month }\end{array}$}} & 1028.0 & 229.53 & 956.4 & 1099.5 & & & \\
\hline & & & \multirow{2}{*}{1119.8} & 215.53 & 1052.6 & 1186.9 & & & \\
\hline & \multicolumn{2}{|c|}{$12^{\text {th }}$ month } & & 206.63 & 1019.5 & 1148.2 & & & \\
\hline \multirow{4}{*}{ Protein } & \multicolumn{2}{|c|}{ Baseline } & 29.73 & 7.784 & 27.30 & 32.15 & \multirow{4}{*}{3.45} & \multirow{4}{*}{42} & \\
\hline & \multicolumn{2}{|c|}{$3^{\text {rd }}$ month } & 27.87 & 6.01 & 26.00 & 29.75 & & & 0.03 \\
\hline & $6^{\text {th }}$ mont & & 31.56 & 8.70 & 28.85 & 34.27 & & & \\
\hline & $12^{\text {th }} \mathrm{mon}$ & & 30.19 & 7.77 & 27.77 & 32.61 & & & \\
\hline Fat & Baseline & & 21.44 & 7.61 & 19.07 & 23.82 & & & \\
\hline & $3^{\text {rd }}$ mont & & 18.93 & 5.14 & 17.32 & 20.53 & 1.96 & 42 & 0.35 \\
\hline & $6^{\text {th }}$ mont & & 21.30 & 6.44 & 19.29 & 23.31 & & & \\
\hline & $12^{\text {th }} \mathrm{mon}$ & & 20.88 & 6.34 & 18.90 & 22.86 & & & \\
\hline & & & Post-H & & & & & & \\
\hline & & & Protein & gm) & & & & & \\
\hline & aseline & & & d month & & $6^{\text {th }}$ & & & \\
\hline $\begin{array}{l}3^{\text {rd }} \\
\text { month }\end{array}$ & $6^{\text {th }}$ month & $\begin{array}{l}12^{\text {th }} \\
\text { month }\end{array}$ & Baseline & $6^{\text {th }}$ month & $\begin{array}{l}12^{\text {th }} \\
\text { month }\end{array}$ & Baseline & $\begin{array}{l}3^{\text {rd }} \\
\text { month }\end{array}$ & & month \\
\hline 0.56 & 0.65 & 1.00 & 0.56 & 0.08 & 0.59 & 0.65 & 0.08 & 0 . & \\
\hline
\end{tabular}

a: Repeated measure ANOVA used for intra-group comparison at different time intervals

b: Post-hoc testing of ANOVA: Bonferroni

$P$ value significant at $5 \%$ level of significance $(\mathrm{p}<0.05)$

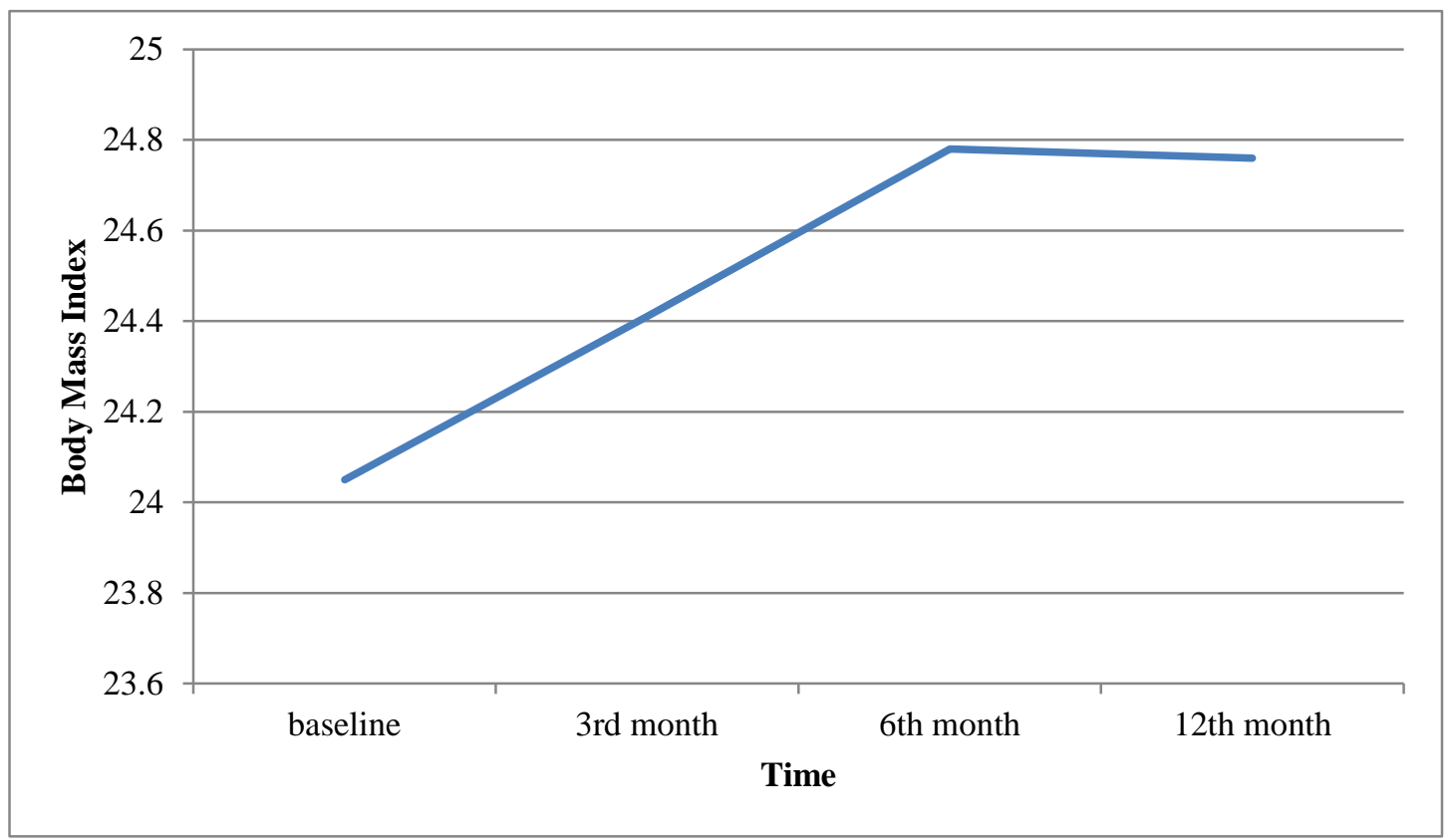

Figure 1: Comparison of BMI (Body Mass Index) at baseline, $3^{\text {rd }}, 6^{\text {th }}$ and $12^{\text {th }}$ months Repeated measure ANOVA used for intra-group comparison at different time intervals $P$ value significant at $5 \%$ level of significance $(p<0.05)$ 


\section{DISCUSSION}

The present study was carried out to compare the chewing ability, oral health related quality of life and nutritional status before and after insertion of complete denture amongst edentulous patients visiting a dental college in Pune.

Free dental treatment is provided by the dental college at reasonable rate, or probably free. This could be the reason that people who report to the dental college belong to lower socioeconomic status. This may have led to misrepresentation of all the socioeconomic classes in this study. Hence, the cohort studied represented those with lower education and poor income. A study done among Brazilian and Canadian independently living elderly people showed the number of remaining teeth was related to greater education and higher income status for that population (1).

The chewing ability questionnaire was found useful in evaluating the chewing ability of patients after wearing the denture. Hirai $\mathrm{T}$ et al has also suggested that food intake questionnaire was useful in evaluating masticatory functions in complete denture wearer (16).

In the present study, improvement in the chewing ability was observed during a period of 12 months after denture insertion which was statistically significant but the improvement from $3^{\text {rd }}$ month to $12^{\text {th }}$ month was not statistically significant. This may be due to the fact that patients developed a pattern of functioning and adapting their diet to complete dentures over a period of time and probably good denture fit and stability of complete denture might have also played a role in improving the chewing ability. The type of denture Implant supported / Valplast could have improved the chewing ability between $3^{\text {rd }}, 6^{\text {th }}$ and $12^{\text {th }}$ months. Muller $\mathrm{K}$ reported in his study that edentulous patients receiving complete denture one year back had difficulty in chewing hard food when compared with the edentulous patients receiving implant-supported over-denture during the same time period (17).

Geriatric Oral Health Assessment Index (GOHAI) is an example of a patient-based assessment of oral health problems commonly affecting older adults (6). As GOHAI is able to detect oral health changes over time and to measure the effect of oral treatment (9), GOHAI was used in the present study to evaluate quality of life. In the present study, GOHAI was found to be a simple and effective method of evaluating the oral health related quality of life of the edentulous patients receiving complete denture.

The present study indicated an improvement in quality of life among edentulous patients after complete denture insertion. It has also been demonstrated by Veyrune J L et al (9) that oral health quality of life of edentulous persons is less than that of dentate persons'. Complete denture improves the quality of life of edentulous persons as it contributes to better appearance and improved social and functional comfort. Thus, it was confirmed by the study that edentulous patients with less initial GOHAI score benefitted after placement of new dentures which increased their quality of life over a period of 12 months. The results of the present study are consistent with other studies conducted by Shigli K et al (6) which showed changes in GOHAI, 1 month after placement of denture in completely edentulous patients reporting to the Department of Prosthodontics in a private dental college in Madhya Pradesh. During the study period, high statistically significant changes in GOHAI amongst patients were observed. (6) Koshino $\mathrm{H}$ et al showed in his study that insertion of denture enhances the degree of eating satisfaction which in turn contributes to psychological health and improves the Quality of Life (18). Similar results were found in this study amongst participants who showed improved Oral Health Related Quality of Life.

In the present study, the food in-take/eating pattern amongst edentulous patients improved over 12 months period after insertion of complete denture. Edentulous patients reported good food in-take and better ability to chew hard food. The nutritive value of food in-take for energy and fat did not show significant difference, probably because most of the patients belonged to upper lower socio-economic status having poor education and lower income, and most of them were farmers. They reported that breakfast was light with tea and biscuits, lunch consisted of roti (jowar / bajra) and dal and vegetables. In the evening they had tea and at dinner rice, dal, subji (cooked vegetables) and roti (jowar / bajra) was consumed. Probably their energy intake would not have been met as these farmers had to fend for themselves. Though jowar and bajra could provide 
energy, the participants did not consume enough rotis. Fat did not show significant difference during the study time period of 12 months as oil, ghee and fat from vegetable sources or meat are expensive and are less consumed by the lower class. Protein in grams showed a slight significant improvement. However, post hoc test (within group) for protein did not show any significant differences over 12 months. In the present study, Body Mass Index (BMI) of the study participants increased from baseline to 12 months, and the difference was statistically significant. The relative percentage of body fat at different BMIs clearly varies within populations. It depends on environmental factors such as the amount of physical activity and physiological factors as observed in the differences between rural and urban populations in India (19).

The results of the present study are not consistent with a study conducted by Paturu R et al (4) who showed that after insertion of complete denture there was a statistically significant increase in nutrition during the study period. A study by Hung $\mathrm{H} \mathrm{C}$ et al (3) found significant associations between changes in dental status and dietary intake of specific nutrients suggesting change in dietary in-take owing to tooth loss could contribute to increased risk of chronic disease that has been associated with poor dentition. No similar results were found among edentulous participants in this study. A study by Moynihan PJ (5) indicated that the edentulous populations consume diets low in non-starch polysaccharides which include whole meal bread, cereals, vegetables and fruits than the dentate people. Also, another study conducted by Lee $\mathrm{J} \mathrm{S}$ et al(7) showed the edentulous elderly had significantly lower in-take of energy from protein than compared with dentate elderly. The results of the present study are not consistent with the study conducted by Wostmann B which stated that prosthetic treatment (new full dentures, new removable denture and new fixed restoration) alone is not adequate to attain a significant improvement in the nutritional status (2) Sheiham conducted a study on nutrient in-take in the form of energy, protein, fat, carbohydrate and vitamins among older people in which he concluded that people with 21 or more natural teeth consumed more of nutrients than those with fewer teeth (20).
The study conducted by Paturu et al showed no significant difference in BMI among first time denture wearer patients after a period of 2 months (4), whereas all the participants in the present study were first time denture wearers, they showed significant change in BMI over 12 months. The nutrition questionnaire evaluated before and after treatment procedure showed a significant difference. There was increase in the frequency of food in-take and in-take of fruits and vegetable in the patients among the present study. However, the study had few limitations. As it was conducted in one dental college, the results cannot be generalized. Moreover, the edentulous patients belonged to low socioeconomic status only. The study also involved 1 day (24 hours) diet chart. Thus, the quantity of food consumed may be overor underestimated and that food in-take on a single day may not be representative of the usual in-take. Serving unit (katori, bowl, spoon) used for measuring food item might have varied from house to house. The energy, protein and fat value were measured as per serving unit. Hence, the accuracy of nutritive value may be questionable. As the investigator was not blinded during recording the data, it could have introduced bias.

To conclude, this study showed that chewing ability and oral health related quality of life improved after insertion of complete denture amongst edentulous participants visiting a dental college in Pune. BMI (Body Mass Index) and food in-take questionnaire showed statistically significant improvement over 12 months. Significant difference was not seen for energy, fat and protein.

\section{REFERENCES}

1. Joaquim AMC, Wyatt CCL, Aleksejuniene J, Greghi SLA, Pegoraro LF, Kiyak H A. A comparison of the dental health of Brazilian and Canadian independently living elderly. Gerodontology 2010; 27: 258-265.

2. Wostmann B, Michel K, Brinkert B, Meichheier-Weskott A, Rehmann P, Balkenhol M. Influence of denture Improvement on the nutritional status and quality of life on geriatric patients. J Dent 2008; 36:816-21. 
3. Hung HC, Walter W, Ascherio A, Rosner B, Rimm E, Joshipura KJ. Tooth loss and dietary intake. JADA 2003; 134:1185-92.

4. Paturu R, Veeravalli PT, Vaidyanathan AK, Grover M. Evaluation of Nutritional Status and Eating Pattern in First and Second-Time Denture Wearers: A Prospective 60 Days (2 Months) Pilot Study. J Indian Prosthodont Soc. 2011; 11(3):156.

5. Moynihan PJ, Snow S, Jepson NJA, Butler TJ. Intake of non-starch polysaccharide (dietary fiber) in edentulous and dentate persons: an observational study. Br Dent J.1994; 177:24347.

6. Hutton B, Feine J, Morais J. Is there an association between edentulism and nutritional state? J Can Dent Assoc.2002; 68(3):182-7.

7. Lee JS, Weyant RJ, Corby P, Kritchevsky SB, Harris TB, Rooks R et al. Edentulism and nutritional status in a biracial sample of well functioning, community-dwelling elderly: the health, Aging, and Body Composition study. Am J Clin Nutr.2004; 79:295-302.

8. Shigli K, Hebbal M. Assessment of change in oral health-related quality of life among patients with complete denture before and 1 month post-insertion using geriatric oral health assessment index. Gerodontology 2010; 27:167-73.

9. Gil-Montoya JA, Subira C, Ramon, JM, and Gonzalez-Moles MA. Oral health related quality of life and nutrition status .J Public Health Dent 2008; 2:68-72.

10. Veyrune JL, Tubert-Jeannin S, Dutheil C, Riordan PJ. Impact of new prostheses on the oral health related quality of life of edentulous patients. Gerodontology 2005; 22:3-9.

11. Berner Y N. Assessment tools for nutritional status in the elderly. IMAJ 2003; 5: 365-67.

12. Rao S. Nutritive values of some Indian food preparations. Agharkar Research Institute, Department of Biometry and Nutrition. $1^{\text {st }}$ edition. Secretary, Maharashtra Association for the Cultivation of Science, Published by Research Institute. Pune (Maharashtra); 1992.

13. Reddy NS,Reddy NA,Narendra R,Reddy SD.Epidemiological survey on Edentulousness.J Contemp Dent Pract.2012 Jul1;13(4) 562-570.
14. Dental council of India. National Oral Health survey 2002-2003, India. Published by Ministry of Health and Family Welfare; 2004.

15. Kumar N, Shekhar C, Kumar P, Kundu AS. Kuppuswamy's Socioeconomic Status ScaleUpdating for 2007. Indian J Pediatr 2007; 74:1131-32.

16. Hirai $T$, Ishijima $T$, Koshino $H$. Age-related change of masticatory function in complete denture wearers: evaluation by a sieving method with peanuts and a food intake questionnaire method. Int J Prosthodont 1994; 7(5):454-60.

17. Muller K, Morais J, Feine J. Nutritional and Anthropometric analysis of edentulous patients wearing Implant Overdenture or Conventional Dentures. Braz Dent J 2008; 19:145-150.

18. Koshino H, Hirai T, Ishijima T, Tsukagoshi H, Ishigami T. Quality of life and masticatory function in denture wearers. J Oral Rehabil 2006; 33:323-29.

19. Barba C, Cavalli-Sforza T, Jeffery Cutter J, Darnton-Hill I, Deurenberg P, DeurenbergYap M et al. Appropriate body-mass index for Asian populations and its implications for policy and intervention strategies. The Lancet 2004; 363: 157.

20. Sheiham A, Steele JG, Marcenes W, Lowe C, Finch S, Bates CJ et al. The relationship among dental status, nutrient intake and nutritional status in older people. $J$ Dent Res 2001; 80:408-13. 